\title{
Methods of adaptability and stability applied to eucalyptus breeding
}

\author{
Osmarino Pires dos Santos( ${ }^{(1)}$, Ivan Ricardo Carvalho(2), Maicon Nardino(2), Tiago Olivoto(3), \\ Alan Junior de Pelegrin ${ }^{(2)}$, Vinícius Jardel Szareski(2), Mauricio Ferrari(2), Andrei Caíque Pires Nunes ${ }^{(4)}$, \\ Gustavo Henrique Demari(2), Francine Lautenchleger ${ }^{(5)}$, Velci Queiróz de Souza ${ }^{(6)}$ and Luciano Carlos da Maia(2) \\ (1)Celulose Riograndense, Rua São Geraldo, № 1.680, Ermo, CEP 92500-000 Guaíba, RS, Brazil. E-mail: osmarino.santos@cmpcrs.com.br \\ (2)Universidade Federal de Pelotas, Centro de Genômica e Fitomelhoramento, CEP 96050-500 Capão do Leão, RS, Brazil. E-mail: \\ carvalho.irc@gmail.com, nardinomn@gmail.com, pelegrinagro@gmail.com, viniciusszareski@gmail.com, ferraritatu@gmail.com, \\ ghdemari@hotmail.com, lucianoc.maia@gmail.com ${ }^{(3)}$ Universidade Federal de Santa Maria, Avenida Roraima, no 1.000, Cidade Universitária, \\ Camobi, CEP 97105-900 Santa Maria, RS, Brazil. E-mail: tiagoolivoto@gmail.com ${ }^{(4)}$ Universidade Federal de Viçosa, Avenida P.H. Rolfs, \\ s/no, CEP 36570-900 Viçosa, MG, Brazil. E-mail: andreicaique@yahoo.com.br (5)Universidade Estadual de Maringá, Departamento de \\ Ciências Agronômicas, Avenida Colombo, no 5.790, CEP 87020-900 Maringá, PR, Brazil. E-mail: francinelautenchleger@hotmail.com \\ (6)Universidade Federal do Pampa, Rua 21 de Abril, no 80, São Gregório, CEP 96450-000 Dom Pedrito, RS, Brazil. E-mail: velciq@gmail.com
}

Abstract - The objective of this work was to evaluate the consistency of the methods of Annicchiarico, Lin \& Binns, Wricke, and factor analysis in identifying eucalyptus clones with stability, adaptability, and high productive potential. Eight-four clones, with three years of age, from the genetic breeding program of the company CMPC Celulose Riograndense were used. Three field experiments were carried out in a randomized complete block design, in an $84 \times 3$ factorial arragement, with 20 replicates of one plant per plot. The clones were evaluated as to diameter at breast height, plant height, and volume of wood. The methods of Annicchiarico and Lin \& Binns are highly correlated with each other, and their use together with the method of Wricke is a sound strategy for the evaluation of eucalyptus clones. The factor analysis identified broadly adaptable clones, and some of them were the same ones identified by the methods of Annicchiarico and Lin \& Binns. The use of the mean classification of the clones, along with the factor analysis, is efficient to identify the most adapted, stable, and productive ones among a high number of genotypes.

Index terms: Eucalyptus, average ranking, experimental planning, factor analysis, selection.

\section{Métodos de adaptabilidade e estabilidade aplicados ao melhoramento de eucalipto}

Resumo - O objetivo deste trabalho foi avaliar a consistência dos métodos de Annicchiarico, Lin \& Binns, Wricke e de análise fatorial na identificação de clones de eucalipto com estabilidade, adaptabilidade e alto potencial produtivo. Foram utilizados 84 clones, com três anos de idade, provenientes do programa de melhoramento genético da empresa CMPC Celulose Riograndense. Três experimentos de campo foram realizados em delineamento de blocos ao acaso, em arranjo fatorial 84x3, com 20 repetições de uma planta por parcela. Os clones foram avaliados quanto a diâmetro à altura do peito, altura da planta e volume de madeira. Os métodos de Annicchiarico e Lin \& Binns são altamente correlacionados entre si, e seu uso em conjunto com o método de Wricke é uma estratégia apropriada para avaliação de clones de eucalipto. A análise fatorial identificou clones amplamente adaptáveis, e alguns deles foram os mesmos identificados pelos métodos de Annicchiarico e Lin \& Binns. O uso da classificação média dos clones, juntamente com a análise fatorial, é eficiente para identificar os mais adaptados, estáveis e produtivos, entre um elevado número de genótipos.

Termos para indexação: Eucalyptus, ranque médio, planejamento experimental, análise de fatores, seleção.

\section{Introduction}

Eucalyptus breeding programs are usually based on selection among and within half-sibling progenies, in order to identify the best clones in the final breeding period (Resende et al., 2012). For this, such clones are evaluated in different environments before final selection and commercialization. Some studies have shown the occurrence of genotype $\mathrm{x}$ environment interaction $(\mathrm{G} \times \mathrm{E})$ in eucalyptus clones (Nunes et al., 2002; Rocha et al., 2006; Rosado et al., 2012) and, therefore, it is important to carry out studies aiming at identifying specific clones for each environment. 
Traditionally, the process of investigating $\mathrm{G} \times \mathrm{E}$ interactions has been through the analysis of variance (Anova) in groups (sites) of experiments; however, the simple analysis of this component of variance does not provide detailed information about the behavior of each clone in each environmental condition (Cruz et al., 2012). In this sense, the analyzes of adaptability and stability based on the Anova, such as those of Annicchiarico (1992) and Wricke (1965), and in a nonparametric analysis, such as that of Lin \& Binns (1988), allow to identify clones with predictable behavior and responsive environmental conditions. In addition, the factor analysis, proposed by Murakami \& Cruz (2004), comprehends the analysis of adaptability and grouping of homogeneous environments.

The use of more than one method in the assessment of adaptability and stability has been a common practice and has shown that some methods are somewhat redundant (Lin \& Binns, 1991; Silva \& Duarte, 2006; Pereira et al., 2009; Carvalho et al., 2014).

In Eucalyptus breeding, due to the long cycle of the species, high operational costs, and to the use of vast and heterogeneous areas, the adopted strategies for the selection of clones must be the most sound and precise ones. Therefore, studies regarding the phenotypic adaptability and stability of this species are essential.

The objective of this work was to evaluate the consistency of the methods of Annicchiarico (1992), Lin \& Binns (1988), Wricke (1965), and factor analysis (Murakami \& Cruz, 2004) in identifying eucalyptus clones with stability, adaptability, and high productive potential.

\section{Materials and Methods}

Three field experiments were carried out in 2012 in the areas of the company CMPC Celulose Riograndense, in the municipalities of Eldorado do Sul (Boa Vista horticultural forest), Butiá (Morro Vermelho horticultural forest), and São Gabriel (Cerro do Batovi horticultural forest), all located in the state of Rio Grande do Sul, Brazil. The experiments were planted in a $3.50 \times 2.14-\mathrm{m}$ spacing and conducted according to the company's operating procedures. Information on the three environments where the tests were implemented are shown in Table 1.

Eighty-four Eucalyptus clones were evaluated in each environment (Table 2). A randomized complete block design was used, in a factorial arrangement $84 \times 3$, arranged in 20 replicates, with one plant per plot. The clones were assessed in the third year with measurements of diameter at breast height $(\mathrm{DBH}, \mathrm{cm})$, total plant height $(\mathrm{PH}, \mathrm{m})$, and volume of wood (VOW, $\left.\mathrm{m}^{3}\right)$. DBH was measured with a diameter tape, and the total height was obtained with the relascope. The VOW, with the bark, was estimated according to the model of Leite et al. (1995):

$$
\begin{aligned}
& \text { VOW }=0.000048 \times \mathrm{DHB}^{1.720483} \times \mathrm{PH}^{1.180736} \times \\
& \exp ^{(-3.00555) \times(\mathrm{t} \times / \mathrm{DBH})} \times\left[0-(\mathrm{d} / \mathrm{DHB})^{1+0.228531 \times \mathrm{d}}\right]+\varepsilon
\end{aligned}
$$

where $\mathrm{DBH}$ is the diameter at $1.3 \mathrm{~m}$ from the soil; $\mathrm{PH}$ is the total height; $t x$ is equal to 0 , for volume estimates with bark, and to 1 for estimates without bark; $d$ is the upper commercial diameter; and $\varepsilon$ is the experimental error.

The data were tested for homogeneity of variances and heteroscedasticity of residues. Afterwards, a joint analysis of variance was performed using Snedecor's F-test, at $5 \%$ probability. The averages of the genotypes were grouped by the Scott-Knott test, also at 5\% probability.

The evaluations for adaptability and phenotypic stability of $\mathrm{DBH}, \mathrm{PH}$, and VOW were performed with

Table 1. Geographic location and soil and climatic conditions of the environments evaluated in the state of Rio

\begin{tabular}{|c|c|c|c|}
\hline Descriptor & Boa Vista & $\begin{array}{c}\text { Morro } \\
\text { Vermelho }\end{array}$ & $\begin{array}{c}\text { Cerro do } \\
\text { Batovi }\end{array}$ \\
\hline Municipality & $\begin{array}{l}\text { Eldorado } \\
\text { do Sul }\end{array}$ & Butiá & São Gabriel \\
\hline $\begin{array}{l}\text { Geographic } \\
\text { coordinates }\end{array}$ & $\begin{array}{l}-30.0689 \\
-51.4470\end{array}$ & $\begin{array}{l}-30.2750 \\
-52.1005\end{array}$ & $\begin{array}{l}-30.4470 \\
-54.5342\end{array}$ \\
\hline Altitude (m) & 75 & 188 & 139 \\
\hline Previous occupation & Forest & Forest & Native field \\
\hline Soil type & Ultisol & Ultisol & Ultisol \\
\hline Mean temperature $\left({ }^{\circ} \mathrm{C}\right)$ & 18.2 & 18.2 & 20.2 \\
\hline $\begin{array}{l}\text { Absolute minimum } \\
\text { temperature }\left({ }^{\circ} \mathrm{C}\right)\end{array}$ & 2.21 & 2.21 & 0.3 \\
\hline $\begin{array}{l}\text { Absolute maximum } \\
\text { temperature }\left({ }^{\circ} \mathrm{C}\right)\end{array}$ & 34.9 & 34.9 & 37.3 \\
\hline Frost risk & Low & Low & High \\
\hline $\begin{array}{l}\text { Relative } \\
\text { humidity (\%) }\end{array}$ & 82.2 & 82.2 & 72.4 \\
\hline Rainfall (mm) & 1570 & 1570 & 1965 \\
\hline
\end{tabular}
Grande do Sul, Brazil. 
the methods of: Annicchiarico (1992) and Wricke (1965), based on the Anova; Lin \& Binns (1988), based on the nonparametric analysis; and factor analysis, proposed by Murakami \& Cruz (2004). The stratification (clustering) of the environments was performed according to the magnitude of the factorial loads obtained after 50 rotations with the "varimax" method. The scores were plotted in relation to the factors, and it was possible to identify the clones with specific adaptability to the regions determined by the factors (quadrants II and IV of the graph), clones with wide adaptability (quadrant I), as well as clones with low performance (quadrant III).

For each studied variable, the association between the methods was evaluated by the correlation coefficient (Spearman) applied to the rank of each genotype, considering the parameters and the concept of adaptability and stability of each method. In the methods of Wricke and Lin \& Binns, rank 1 was assigned to the clone with the lowest estimate of $\omega_{\mathrm{i}}$ and $\mathrm{P}_{\mathrm{i}}$, respectively, successively, until the last rank, which presented the largest of these estimates. In the method of Annicchiarico, contrastingly, rank 1 was

Table 2. Description of the Eucalyptus clones analyzed in three environments, with their respective species and crosses.

\begin{tabular}{|c|c|c|c|}
\hline No. & Species & $\begin{array}{l}\text { Number } \\
\text { of clones }\end{array}$ & $\begin{array}{c}\text { Total no. } \\
\text { of clones } \\
(\%)\end{array}$ \\
\hline 1 & E. (grandis $x$ urophylla) $\mathrm{x}$ not informed & 31 & 36.90 \\
\hline 2 & E. urophylla $\mathrm{x}$ E. globules & 21 & 25.00 \\
\hline 3 & E. (grandis $x$ urophylla $) \times$ E. globulus & 12 & 14.29 \\
\hline 4 & E. saligna $\mathrm{x}$ not informed & 4 & 4.76 \\
\hline 5 & $\begin{array}{l}\text { E. (grandis } \mathrm{x} \text { urophylla) } \mathrm{x} \text { E. (urophylla } \\
\mathrm{x} \text { globulus) }\end{array}$ & 3 & 3.57 \\
\hline 6 & E. (grandis $\mathrm{x}$ saligna $) \mathrm{x}$ notinformed & 2 & 2.38 \\
\hline 7 & E. grandis $\mathrm{x}$ E.globulus & 2 & 2.38 \\
\hline 8 & E. (grandis $\mathrm{x}$ urophylla $) \times$ E.maidenii & 2 & 2.38 \\
\hline 9 & E. (grandis $\mathrm{x}$ urophylla) $\mathrm{x}$ E.viminalis & 2 & 2.38 \\
\hline 10 & E. urophylla $\mathrm{x}$ not informed & 1 & 1.19 \\
\hline 11 & $\begin{array}{l}\text { E. (dunnii x grandis) } \times \text { E. (urophylla } \mathrm{x} \\
\text { globulus })\end{array}$ & 1 & 1.19 \\
\hline 12 & E. (dunnii $\mathrm{x}$ grandis $) \mathrm{x}$ E.viminalis & 1 & 1.19 \\
\hline 13 & E. saligna & 1 & 1.19 \\
\hline 14 & E. (dunnii $\mathrm{x}$ grandis $) \mathrm{x}$ not informed & 1 & 1.19 \\
\hline Total & & 84 & 100.00 \\
\hline
\end{tabular}

attributed to the clone with the highest estimate of $\omega i$; afterwards, the average of the ranking of the four methods studied and the productive ranking of the clones were established. This average was ranked, and the clones with the ten best averages were presented. All statistical procedures were performed using the Genes software (Cruz, 2013).

\section{Results and Discussion}

The analysis of joint variance revealed a significant interaction of clones and environments for $\mathrm{DBH}, \mathrm{PH}$, and VOW. The $\mathrm{G} \times \mathrm{E}$ interaction hampers giving a standard recommendation for all sites (Rosado et al., 2012).

According to the Scott-Knott test, six groups were formed for DBH. The group with the highest averages (A) was composed of 18 clones (21\%) (Table 3). Plant height showed high variability, revealing the potential of this trait for the selection of superior clones. Four groups were formed for $\mathrm{PH}$. The group with the highest averages (A) was composed by 21 clones $(25 \%)$. For VOW, six groups were formed, with the highest averages only in five clones (5\%).

Clones 9, 59, and 72 had the highest $\mathrm{DBH}, \mathrm{PH}$, and VOW averages (Table 3). A previous study with 21 clones, 36 months old, from the Cenibra breeding program, showed averages of $11 \mathrm{~cm}, 16.5 \mathrm{~m}$, and 0.07 $\mathrm{m}^{3}$ for these same traits, respectively (Rosado et al., 2012). The results found, therefore, revealed clones with high productive potential for selection, which can be used as a source of genetic variation for Eucalyptus breeding programs.

The most stable material for $\mathrm{DBH}$, identified by the method of Annicchiarico, was clone 59 (Table 4). According to the methods Lin \& Binns and Wricke, however, clones 9,26 , and 3 showed the best stability and adaptability results. Genotype 59 was ranked first, regarding stability, with the second highest DBH. Moreover, this genotype was classified as the first, second, and tenth most adapted and stable by the methods of Annicchiarico, Lin \& Binns, and Wricke, respectively.

Clone 59 also presented the highest $\mathrm{PH}$ values (Table 5), and it was classified as the first most adapted and stable according to the methods of Annicchiarico and Lin \& Binns. As for VOW, this clone once more had the best results, being classified as the first and second 
most adapted and stable, according to the methods of Annicchiarico and Lin \& Binns, respectively (Table 6). It is important to highlight that clone 59 also showed the second highest average of VOW. In a study with sugarcane (Sacharum officinarum L.), Paula et al. (2013) identified that the methods of Lin \& Binns and Annicchiarico were similar as to their classification of genotypes, with $100 \%$ of agreement for the first 10 ranking positions.

Of the 30 analyzed correlation pairs, $83 \%$ were significant at $1 \%$ probability. For the three studied variables, a high association $\left(\mathrm{r}_{\mathrm{s}}>0.90\right)$ was observed between genotype rank for the evaluated traits and their classification regarding the parameters of adaptability and stability of the methods of Annicchiarico and Lin $\&$ Binns (Table 7). These results indicate that these methods can be used as tools for identifying stable clones among the most productive ones. The positive correlation $\left(r_{s}>0.90\right)$ between these methods, however, shows that their joint use should be optional, since their results converge to a common point. Similar findings were observed by Silva \& Duarte (2006) and by Pereira et al. (2009), who found high positive associations between them.
Although the methods of Annicchiarico and Lin $\&$ Binns are based on different statistical principles, the genotypic classification for the three variables analyzed was similar (Tables 4, 5, and 6). For example, clone 59 was classified as the most stable by these two methods regarding $\mathrm{PH}$ (Table 5), but as the first and second, respectively, regarding VOW (Table 6). These results may be associated with the higher average values observed for this clone (Table 3), since both methods use the superiority of the clone, in relation to the maximum average response of each environment, as a principle for determining adaptability and stability (Cruz et al., 2012).

The parameters of adaptability and stability of the method of Wricke showed relatively low associations $\left(r_{s}<0.50\right)$ with the production averages of DBH, PH, and VOW (Table 7). The methods of Annicchiarico and Wricke were lowly correlated to each other. Thus, the joint use the methods of Annicchiarico or Lin \& Binns with the Wricke method must be favored by the breeders, since their parameters can reveal detailed information, which could aid in choosing the best strategy for selection.

In the average ranking of the three evaluated variables, clone 59 occupied the first order (Table 8).

Table 3. Genotype grouping ${ }^{(1)}$ according to their averages for diameter at breast height, plant height, and volume of wood.

\begin{tabular}{lccc}
\hline Group & $\begin{array}{c}\text { Highest } \\
\text { average }\end{array}$ & $\begin{array}{c}\text { Lowest } \\
\text { average }\end{array}$ & Genotype $^{(2)}$ \\
& & & Diameter at breast height $(\mathrm{cm})$ \\
A & 17.614 & 15.790 & $9,59,64,15,72,62,11,10,58,65,68,83,75,77,71,1,34,82$ \\
B & 15.494 & 13.460 & $16,74,76,12,63,13,8,26,69,67,66,30,33,46,2,51,79,52,60,84,40,29,54,4,14,17,32,20,70,78$ \\
C & 13.311 & 12.002 & $55,31,24,73,56,53,18,61,47,7,35,50,80,21,39,27,42,81$ \\
D & 11.641 & 11.021 & $5,3,41,43,57,28,36$ \\
E & 10.807 & 9.850 & $49,22,19,6,48$ \\
F & 9.581 & 8.140 & $25,37,23,44,45,38$ \\
\hline & & & Plant height (m) \\
A & 17.768 & 16.336 & $59,9,77,30,13,14,62,72,83,34,29,70,40,67,12,81,46,8,69,74,71$ \\
B & 16.221 & 14.853 & $58,82,16,60,84,51,75,54,26,1,24,20,31,4,11,64,65,68,61,10,47,15,70,17,32,7,73,78,55,52,18,2,3,63,56,33,66$ \\
C & 14.771 & 13.071 & $22,53,39,76,41,27,35,43,36,21,50,42,57,28,80,37,19,5,25$ \\
D & 12.822 & 10.966 & $49,48,23,6,44,38,45$ \\
\hline & & & Volume of wood $\left(\mathrm{m}^{3}\right)$ \\
A & 0.215 & 0.188 & $9,59,72,64,66$ \\
B & 0.183 & 0.161 & $62,15,77,83,10,58,65,11,34,68,75,71,74,1$ \\
C & 0.156 & 0.134 & $54,33,52,17,4,14,73,70,18,32,42$ \\
D & 0.127 & 0.118 & $30,16,13,46,12,82,67,69,79,26,8,63,24,84,40,76,29,60,2,51$ \\
E & 0.115 & 0.081 & $53,20,31,78,47,35,81,55,39,21,61,56,27,41,22,7,43,36,80,50,3,5$ \\
F & 0.071 & 0.032 & $28,57,49,19,37,48,6,23,25,44,45,38$ \\
\hline
\end{tabular}

(1)The groups were formed according to the Scott-Knott test, at $5 \%$ probability. ${ }^{(2)}$ The order of the genotype in each group is presented according to their decreasing average ranking for each variable. 
Table 4. Estimates of the adaptability and phenotypic stability parameters for diameter at breast height (DBH, $\mathrm{cm}$ ) of 84 Eucalyptus genotypes (G) for the methods of Annicchiarico (ANN), Lin \& Binns (L\&B), and Wricke (W), as well as their respective ranks $(\mathrm{C})$ according to their adaptability and stability classification in each method.

\begin{tabular}{|c|c|c|c|c|c|c|c|c|c|c|c|c|c|c|c|c|c|}
\hline \multirow[t]{2}{*}{ G } & \multicolumn{2}{|c|}{$\mathrm{DBH}$} & \multicolumn{2}{|c|}{ ANN } & \multicolumn{2}{|c|}{ L\&B } & \multicolumn{2}{|c|}{ Wricke } & \multirow[t]{2}{*}{ G } & \multicolumn{2}{|c|}{ DBH } & \multicolumn{2}{|c|}{ ANN } & \multicolumn{2}{|c|}{ L\&B } & \multicolumn{2}{|c|}{ Wricke } \\
\hline & Average & $\mathrm{C}$ & $\Omega \mathrm{i}$ & $\mathrm{C}$ & $\mathrm{Pi}$ & $\mathrm{C}$ & $\omega \mathrm{i}$ & $\mathrm{C}$ & & Average & $\mathrm{C}$ & $\omega \mathrm{i}$ & $\mathrm{C}$ & $\mathrm{Pi}$ & $\mathrm{C}$ & $\omega \mathrm{i}$ & $\mathrm{C}$ \\
\hline 1 & 15.99 & 16 & 101.3 & 16 & 4.67 & 17 & 73.36 & 34 & 43 & 11.31 & 70 & 73.08 & 50 & 27.1 & 69 & 8.538 & 4 \\
\hline 2 & 14.65 & 33 & 100.1 & 21 & 8.23 & 29 & 18.5 & 7 & 44 & 9.029 & 82 & 12.74 & 82 & 57.3 & 81 & 954.5 & 83 \\
\hline 3 & 11.55 & 68 & 77.26 & 47 & 25.90 & 68 & 18.83 & 9 & 45 & 8.32 & 83 & 12.32 & 83 & 63.3 & 84 & 840.4 & 81 \\
\hline 4 & 14.08 & 42 & 93.43 & 33 & 11,00 & 42 & 28.68 & 14 & 46 & 14.76 & 32 & 70.38 & 54 & 9.06 & 34 & 331.8 & 68 \\
\hline 5 & 11.64 & 67 & 53.46 & 66 & 25.20 & 66 & 175.2 & 59 & 47 & 12.42 & 57 & 59.72 & 64 & 20.1 & 54 & 176.9 & 61 \\
\hline 6 & 10.16 & 77 & 40.95 & 74 & 41.40 & 78 & 391.5 & 72 & 48 & 9.85 & 78 & 65.3 & 61 & 39.8 & 77 & 33.44 & 19 \\
\hline 7 & 12.41 & 58 & 77.10 & 48 & 21,00 & 56 & 64.25 & 30 & 49 & 10.81 & 74 & 32.36 & 78 & 39.2 & 76 & 699.9 & 79 \\
\hline 8 & 15.11 & 25 & 90.12 & 37 & 7.85 & 27 & 103.5 & 41 & 50 & 12.33 & 60 & 62.11 & 62 & 23.5 & 63 & 237.9 & 66 \\
\hline 9 & 17.61 & 1 & 111.6 & 4 & 0.95 & 1 & 125.4 & 46 & 51 & 14.62 & 34 & 94.74 & 29 & 8.41 & 31 & 49.65 & 24 \\
\hline 10 & 16.47 & 8 & 108.3 & 9 & 2.49 & 7 & 63.59 & 29 & 52 & 14.57 & 36 & 101 & 18 & 8.72 & 32 & 8.101 & 3 \\
\hline 11 & 16.48 & 7 & 105.1 & 11 & 2.60 & 8 & 89.77 & 37 & 53 & 12.75 & 54 & 42.31 & 73 & 20.1 & 55 & 510.4 & 76 \\
\hline 12 & 15.32 & 22 & 100.4 & 20 & 5.67 & 21 & 45.89 & 23 & 54 & 14.13 & 41 & 92.42 & 35 & 10.4 & 41 & 32.76 & 18 \\
\hline 13 & 15.11 & 24 & 95.07 & 28 & 6.46 & 23 & 69.47 & 32 & 55 & 13.31 & 49 & 46.45 & 70 & 22.8 & 61 & 714.6 & 80 \\
\hline 14 & 14 & 43 & 78.92 & 46 & 13.20 & 45 & 140.1 & 52 & 56 & 12.75 & 53 & 72.39 & 52 & 19.7 & 52 & 131.7 & 48 \\
\hline 15 & 17.21 & 4 & 115.40 & 2 & 1.410 & 3 & 26.29 & 13 & 57 & 11.26 & 71 & 69.55 & 56 & 28.8 & 71 & 71.34 & 33 \\
\hline 16 & 15.49 & 19 & 104.10 & 12 & 5.40 & 19 & 32.51 & 17 & 58 & 16.42 & 9 & 108.7 & 8 & 2.78 & 9 & 55.72 & 26 \\
\hline 17 & 13.91 & 44 & 91.02 & 36 & 12.10 & 43 & 32.32 & 16 & 59 & 17.36 & 2 & 120.5 & 1 & 0.97 & 2 & 20.11 & 10 \\
\hline 18 & 12.65 & 55 & 48.34 & 69 & 19.80 & 53 & 377.8 & 71 & 60 & 14.42 & 37 & 87.59 & 40 & 9.43 & 38 & 96.62 & 39 \\
\hline 19 & 10.68 & 76 & 51.39 & 68 & 35.70 & 75 & 256.5 & 67 & 61 & 12.54 & 56 & 83.72 & 44 & 19 & 51 & 18.52 & 8 \\
\hline 20 & 13.73 & 46 & 72.37 & 53 & 15.10 & 46 & 211.1 & 64 & 62 & 16.57 & 6 & 109.9 & 6 & 2.28 & 6 & 58.75 & 28 \\
\hline 21 & 12.26 & 62 & 65.83 & 59 & 21.20 & 57 & 137.9 & 49 & 63 & 15.12 & 23 & 87.66 & 39 & 8.26 & 30 & 169 & 58 \\
\hline 22 & 10.75 & 75 & 26.98 & 79 & 33.60 & 74 & 453 & 75 & 64 & 17.31 & 3 & 104.1 & 13 & 1.52 & 4 & 183.8 & 63 \\
\hline 23 & 9.131 & 81 & 7.484 & 84 & 58.60 & 83 & 1207 & 84 & 65 & 16.35 & 10 & 98.78 & 25 & 3.75 & 15 & 143.6 & 53 \\
\hline 24 & 12.91 & 51 & 26.55 & 80 & 22,00 & 59 & 928.3 & 82 & 66 & 14.87 & 29 & 86.24 & 41 & 9.28 & 36 & 110.8 & 43 \\
\hline 25 & 9.581 & 79 & 24.63 & 81 & 49.6 & 80 & 697 & 78 & 67 & 15 & 28 & 92.86 & 34 & 7.06 & 26 & 90.98 & 38 \\
\hline 26 & 15.03 & 26 & 105.10 & 10 & 6.95 & 25 & 3.243 & 1 & 68 & 16.29 & 11 & 104.1 & 14 & 3.41 & 12 & 76.35 & 35 \\
\hline 27 & 12.16 & 64 & 69.40 & 57 & 23.30 & 62 & 125.5 & 47 & 69 & 15.02 & 27 & 98.84 & 24 & 6.68 & 24 & 40.3 & 21 \\
\hline 28 & 11.12 & 72 & 60.80 & 63 & 31.10 & 72 & 157.8 & 55 & 70 & 13.65 & 47 & 65.5 & 60 & 17 & 49 & 377 & 70 \\
\hline 29 & 14.34 & 40 & 99.94 & 22 & 9.52 & 39 & 8.694 & 5 & 71 & 16.02 & 15 & 113.1 & 3 & 3.52 & 14 & 14.94 & 6 \\
\hline 30 & 14.86 & 30 & 85.93 & 42 & 7.88 & 28 & 139.1 & 51 & 72 & 17.18 & 5 & 98.72 & 26 & 1.97 & 5 & 235 & 65 \\
\hline 31 & 13.25 & 50 & 76.32 & 49 & 16.80 & 48 & 117.7 & 44 & 73 & 12.9 & 52 & 85.67 & 43 & 17.3 & 50 & 26.15 & 12 \\
\hline 32 & 13.9 & 45 & 83.24 & 45 & 13.10 & 44 & 99.37 & 40 & 74 & 15.38 & 20 & 110.1 & 5 & 5.47 & 20 & 6.592 & 2 \\
\hline 33 & 14.81 & 31 & 89.50 & 38 & 9.14 & 35 & 88.18 & 36 & 75 & 16.17 & 13 & 109.6 & 7 & 3.16 & 10 & 36.73 & 20 \\
\hline 34 & 15.82 & 17 & 93.77 & 32 & 4.87 & 18 & 162.4 & 56 & 76 & 15.36 & 21 & 101.1 & 17 & 5.8 & 22 & 44.87 & 22 \\
\hline 35 & 12.33 & 59 & 37.19 & 77 & 23.60 & 64 & 580.3 & 77 & 77 & 16.16 & 14 & 100.8 & 19 & 3.45 & 13 & 107.1 & 42 \\
\hline 36 & 11.02 & 73 & 37.27 & 76 & 32.40 & 73 & 425.2 & 74 & 78 & 13.46 & 48 & 72.78 & 51 & 16.3 & 47 & 176.1 & 60 \\
\hline 37 & 9.449 & 80 & 42.79 & 72 & 43.70 & 79 & 138.8 & 50 & 79 & 14.6 & 35 & 93.97 & 31 & 8.76 & 33 & 54.56 & 25 \\
\hline 38 & 8.14 & 84 & 44.11 & 71 & 58,0 & 82 & 149.8 & 54 & 80 & 12.32 & 61 & 66.9 & 58 & 22.4 & 60 & 179.3 & 62 \\
\hline 39 & 12.2 & 63 & 58.77 & 65 & 21.50 & 58 & 165.8 & 57 & 81 & 12 & 66 & 52.27 & 67 & 25.4 & 67 & 359.8 & 69 \\
\hline 40 & 14.37 & 39 & 96.72 & 27 & 9.41 & 37 & 24.11 & 11 & 82 & 15.79 & 18 & 102.1 & 15 & 4.67 & 16 & 57.71 & 27 \\
\hline 41 & 11.36 & 69 & 69.75 & 55 & 28,00 & 70 & 68.17 & 31 & 83 & 16.26 & 12 & 99.71 & 23 & 3.2 & 11 & 124.8 & 45 \\
\hline 42 & 12 & 65 & 40.65 & 75 & 24.4 & 65 & 421.1 & 73 & 84 & 14.41 & 38 & 94.17 & 30 & 9.82 & 40 & 31.76 & 15 \\
\hline
\end{tabular}


Table 5. Estimates of the adaptability and phenotypic stability parameters for plant height ( $\mathrm{PH}, \mathrm{m})$ of 84 Eucalyptus genotypes (G) for the methods of Annicchiarico (ANN), Lin \& Binns (L\&B), and Wricke (W), as well as their respective ranks $(C)$ according to their adaptability and stability classification in each method.

\begin{tabular}{|c|c|c|c|c|c|c|c|c|c|c|c|c|c|c|c|c|c|}
\hline \multirow{2}{*}{ G } & \multicolumn{2}{|c|}{$\mathrm{PH}$} & \multicolumn{2}{|c|}{ ANN } & \multicolumn{2}{|c|}{$L \& B$} & \multicolumn{2}{|c|}{ Wricke } & \multirow{2}{*}{ G } & \multicolumn{2}{|l|}{$\mathrm{PH}$} & \multicolumn{2}{|c|}{ ANN } & \multicolumn{2}{|c|}{$L \& B$} & \multicolumn{2}{|c|}{ Wricke } \\
\hline & Average & $\mathrm{C}$ & $\Omega \mathrm{i}$ & $\mathrm{C}$ & $\mathrm{Pi}$ & $\mathrm{C}$ & $\omega \mathrm{i}$ & $\mathrm{C}$ & & Average & $\mathrm{C}$ & $\omega \mathrm{i}$ & $\mathrm{C}$ & $\mathrm{Pi}$ & $\mathrm{C}$ & $\omega \mathrm{i}$ & $\mathrm{C}$ \\
\hline 1 & 16.01 & 31 & 104.90 & 32 & 3.04 & 30 & 9.85 & 9 & 43 & 14.30 & 66 & 93.64 & 66 & 8.43 & 63 & 4.69 & 3 \\
\hline 2 & 15.07 & 53 & 99.47 & 50 & 6.86 & 54 & 112.67 & 54 & 44 & 11.77 & 82 & 79.02 & 82 & 26.77 & 80 & 415.32 & 78 \\
\hline 3 & 15.03 & 54 & 98.59 & 54 & 5.99 & 49 & 16.62 & 15 & 45 & 10.97 & 84 & 74.89 & 83 & 37.19 & 84 & 897.63 & 84 \\
\hline 4 & 15.88 & 35 & 104.01 & 34 & 3.67 & 34 & 77.22 & 46 & 46 & 16.42 & 17 & 106.15 & 21 & 1.98 & 17 & 108.27 & 52 \\
\hline 5 & 13.37 & 76 & 86.79 & 76 & 12.49 & 74 & 51.84 & 38 & 47 & 15.55 & 42 & 99.85 & 49 & 4.35 & 40 & 187.57 & 68 \\
\hline 6 & 11.91 & 81 & 80.55 & 81 & 27.10 & 81 & 532.18 & 81 & 48 & 12.63 & 79 & 83.03 & 79 & 17.38 & 78 & 58.33 & 40 \\
\hline 7 & 15.40 & 47 & 100.90 & 45 & 4.55 & 42 & 1.44 & 1 & 49 & 12.82 & 78 & 85.66 & 78 & 20.01 & 79 & 386.82 & 76 \\
\hline 8 & 16.40 & 18 & 107.68 & 16 & 2.59 & 27 & 65.07 & 42 & 50 & 14.16 & 69 & 93.91 & 64 & 10.77 & 71 & 125.91 & 58 \\
\hline 9 & 17.73 & 2 & 115.02 & 3 & 0.32 & 3 & 94.59 & 50 & 51 & 16.12 & 27 & 104.32 & 33 & 2.53 & 26 & 89.75 & 49 \\
\hline 10 & 15.59 & 41 & 98.64 & 53 & 7.37 & 57 & 691.42 & 82 & 52 & 15.11 & 51 & 98.14 & 55 & 5.10 & 45 & 25.10 & 20 \\
\hline 11 & 15.85 & 36 & 103.84 & 36 & 3.78 & 36 & 50.73 & 36 & 53 & 14.71 & 60 & 94.70 & 62 & 6.69 & 52 & 121.89 & 57 \\
\hline 12 & 16.53 & 15 & 107.71 & 15 & 1.58 & 13 & 17.84 & 16 & 54 & 16.07 & 29 & 105.52 & 26 & 2.90 & 28 & 7.96 & 6 \\
\hline 13 & 17.15 & 5 & 111.74 & 7 & 0.75 & 7 & 45.96 & 33 & 55 & 15.11 & 50 & 100.12 & 47 & 8.33 & 60 & 240.52 & 71 \\
\hline 14 & 17.14 & 6 & 111.83 & 6 & 0.90 & 8 & 54.09 & 39 & 56 & 14.99 & 56 & 99.02 & 51 & 6.81 & 53 & 60.58 & 41 \\
\hline 15 & 15.52 & 43 & 101.57 & 43 & 4.16 & 37 & 1.67 & 2 & 57 & 14.08 & 71 & 92.86 & 68 & 10.25 & 70 & 75.31 & 45 \\
\hline 16 & 16.19 & 24 & 105.36 & 27 & 2.23 & 20 & 21.65 & 18 & 58 & 16.22 & 22 & 105.91 & 23 & 2.33 & 21 & 13.80 & 14 \\
\hline 17 & 15.49 & 45 & 101.28 & 44 & 4.19 & 38 & 9.10 & 7 & 59 & 17.77 & 1 & 116.21 & 1 & 0.19 & 1 & 11.10 & 12 \\
\hline 18 & 15.10 & 52 & 96.76 & 58 & 5.92 & 48 & 232.55 & 70 & 60 & 16.18 & 25 & 105.76 & 24 & 2.51 & 24 & 34.30 & 27 \\
\hline 19 & 13.38 & 75 & 89.35 & 74 & 15.86 & 76 & 265.91 & 73 & 61 & 15.62 & 40 & 102.60 & 38 & 4.26 & 39 & 29.54 & 26 \\
\hline 20 & 15.93 & 33 & 105.21 & 29 & 4.39 & 41 & 109.59 & 53 & 62 & 17.13 & 7 & 111.90 & 5 & 0.98 & 11 & 49.52 & 35 \\
\hline 21 & 14.16 & 68 & 93.27 & 67 & 10.15 & 69 & 120.34 & 56 & 63 & 14.99 & 55 & 97.92 & 56 & 8.65 & 65 & 330.27 & 74 \\
\hline 22 & 14.77 & 59 & 93.70 & 65 & 8.65 & 64 & 495.84 & 80 & 64 & 15.83 & 37 & 102.33 & 39 & 3.48 & 32 & 131.85 & 59 \\
\hline 23 & 12.13 & 80 & 81.12 & 80 & 28.26 & 82 & 860.93 & 83 & 65 & 15.77 & 38 & 103.19 & 37 & 3.58 & 33 & 27.68 & 24 \\
\hline 24 & 15.94 & 32 & 101.64 & 42 & 4.93 & 44 & 451.45 & 79 & 66 & 14.85 & 58 & 98.65 & 52 & 8.75 & 66 & 178.60 & 66 \\
\hline 25 & 13.07 & 77 & 87.20 & 75 & 17.02 & 77 & 219.54 & 69 & 67 & 16.59 & 14 & 108.36 & 14 & 1.60 & 14 & 27.67 & 23 \\
\hline 26 & 16.02 & 30 & 105.29 & 28 & 3.14 & 31 & 10.10 & 11 & 68 & 15.71 & 39 & 103.85 & 35 & 4.74 & 43 & 68.96 & 44 \\
\hline 27 & 14.46 & 64 & 95.29 & 60 & 8.38 & 61 & 35.37 & 28 & 69 & 16.39 & 19 & 106.96 & 18 & 1.87 & 15 & 9.34 & 8 \\
\hline 28 & 13.85 & 72 & 92.14 & 69 & 12.79 & 75 & 177.85 & 65 & 70 & 15.49 & 44 & 101.83 & 40 & 6.92 & 55 & 265.06 & 72 \\
\hline 29 & 16.95 & 11 & 110.69 & 10 & 0.95 & 10 & 10.00 & 10 & 71 & 16.34 & 21 & 105.55 & 25 & 2.17 & 18 & 117.60 & 55 \\
\hline 30 & 17.25 & 4 & 112.17 & 4 & 0.58 & 4 & 50.82 & 37 & 72 & 17.11 & 8 & 111.45 & 8 & 0.74 & 6 & 38.54 & 31 \\
\hline 31 & 15.92 & 34 & 104.91 & 31 & 3.73 & 35 & 27.60 & 22 & 73 & 15.25 & 48 & 100.04 & 48 & 5.71 & 46 & 65.25 & 43 \\
\hline 32 & 15.48 & 46 & 101.82 & 41 & 7.97 & 59 & 372.54 & 75 & 74 & 16.36 & 20 & 106.74 & 19 & 1.96 & 16 & 11.81 & 13 \\
\hline 33 & 14.97 & 57 & 97.55 & 57 & 5.89 & 47 & 26.85 & 21 & 75 & 16.09 & 28 & 105.00 & 30 & 2.49 & 23 & 7.32 & 5 \\
\hline 34 & 16.97 & 10 & 110.42 & 12 & 0.91 & 9 & 43.03 & 32 & 76 & 14.67 & 62 & 94.30 & 63 & 7.13 & 56 & 172.53 & 64 \\
\hline 35 & 14.36 & 65 & 92.01 & 70 & 8.43 & 62 & 180.12 & 67 & 77 & 17.67 & 3 & 115.20 & 2 & 0.30 & 2 & 48.32 & 34 \\
\hline 36 & 14.17 & 67 & 91.24 & 71 & 9.53 & 68 & 168.33 & 63 & 78 & 15.18 & 49 & 100.46 & 46 & 6.48 & 50 & 79.38 & 47 \\
\hline 37 & 13.45 & 74 & 86.31 & 77 & 12.49 & 73 & 149.49 & 61 & 79 & 16.82 & 12 & 110.68 & 11 & 2.17 & 19 & 82.58 & 48 \\
\hline 38 & 11.12 & 83 & 74.64 & 84 & 31.06 & 83 & 398.57 & 77 & 80 & 13.79 & 73 & 91.05 & 72 & 11.89 & 72 & 105.34 & 51 \\
\hline 39 & 14.70 & 61 & 95.43 & 59 & 6.59 & 51 & 37.90 & 30 & 81 & 16.52 & 16 & 107.15 & 17 & 2.44 & 22 & 145.13 & 60 \\
\hline 40 & 16.64 & 13 & 108.81 & 13 & 1.51 & 12 & 6.21 & 4 & 82 & 16.21 & 23 & 106.10 & 22 & 2.51 & 25 & 22.10 & 19 \\
\hline 41 & 14.51 & 63 & 94.95 & 61 & 7.92 & 58 & 35.96 & 29 & 83 & 17.09 & 9 & 111.38 & 9 & 0.72 & 5 & 29.11 & 25 \\
\hline 42 & 14.15 & 70 & 90.65 & 73 & 9.02 & 67 & 151.29 & 62 & 84 & 16.16 & 26 & 106.18 & 20 & 2.93 & 29 & 18.31 & 17 \\
\hline
\end{tabular}


Clone 62 was also ranked among the first ten clones, composed group A, with the best averages, and were and it is noteworthy that both clones 59 and 62 classified among the most adapted and stable.

Table 6. Estimates of the adaptability and phenotypic stability parameters for volume of wood (VOW, $\mathrm{m}^{3}$ ) of 84 Eucalyptus genotypes (G) for the methods of Annicchiarico (ANN), Lin \&Binns (L\&B), and Wricke (W), as well as their respective ranks $(C)$ according to their adaptability and stability classification in each method.

\begin{tabular}{|c|c|c|c|c|c|c|c|c|c|c|c|c|c|c|c|c|c|}
\hline \multirow{2}{*}{ G } & \multicolumn{2}{|c|}{ VOW } & \multicolumn{2}{|c|}{ ANN } & \multicolumn{2}{|c|}{ L\&B } & \multicolumn{2}{|c|}{ Wricke } & \multirow{2}{*}{ G } & \multicolumn{2}{|c|}{ VOW } & \multicolumn{2}{|c|}{ ANN } & \multicolumn{2}{|c|}{ L\&B } & \multicolumn{2}{|c|}{ Wricke } \\
\hline & Average & $\mathrm{C}$ & $\Omega \mathrm{i}$ & $\mathrm{C}$ & $\mathrm{Pi}$ & $\mathrm{C}$ & $\omega \mathrm{i}$ & $\mathrm{C}$ & & Average & $\mathrm{C}$ & $\omega \mathrm{i}$ & $\mathrm{C}$ & $\mathrm{Pi}$ & $\mathrm{C}$ & $\omega \mathrm{i}$ & $\mathrm{C}$ \\
\hline 1 & 0.16 & 19 & 99.03 & 21 & 0.004 & 19 & 0.05 & 49 & 43 & 0.09 & 67 & 91.11 & 36 & 0.012 & 62 & 0.01 & 14 \\
\hline 2 & 0.13 & 38 & 82.89 & 52 & 0.006 & 29 & 0.00 & 4 & 44 & 0.04 & 82 & 46.41 & 80 & 0.025 & 83 & 0.23 & 83 \\
\hline 3 & 0.08 & 70 & 91.46 & 35 & 0.014 & 68 & 0.01 & 11 & 45 & 0.04 & 83 & 25.34 & 84 & 0.025 & 84 & 0.20 & 79 \\
\hline 4 & 0.12 & 43 & 90.02 & 37 & 0.008 & 45 & 0.02 & 18 & 46 & 0.15 & 24 & 88.38 & 41 & 0.004 & 24 & 0.11 & 67 \\
\hline 5 & 0.08 & 72 & 72.10 & 63 & 0.013 & 64 & 0.01 & 9 & 47 & 0.11 & 55 & 74.11 & 59 & 0.009 & 51 & 0.01 & 15 \\
\hline 6 & 0.05 & 78 & 43.97 & 82 & 0.021 & 79 & 0.16 & 74 & 48 & 0.05 & 79 & 72.72 & 61 & 0.019 & 77 & 0.05 & 46 \\
\hline 7 & 0.09 & 66 & 98.41 & 24 & 0.013 & 65 & 0.03 & 23 & 49 & 0.06 & 76 & 52.36 & 77 & 0.020 & 78 & 0.22 & 81 \\
\hline 8 & 0.14 & 30 & 94.52 & 31 & 0.007 & 37 & 0.04 & 41 & 50 & 0.08 & 71 & 75.92 & 57 & 0.015 & 71 & 0.09 & 61 \\
\hline 9 & 0.22 & 1 & 101.61 & 12 & 0.000 & 1 & 0.18 & 76 & 51 & 0.13 & 39 & 87.60 & 44 & 0.006 & 33 & 0.02 & 20 \\
\hline 10 & 0.17 & 10 & 48.23 & 79 & 0.002 & 5 & 0.14 & 70 & 52 & 0.13 & 42 & 88.06 & 42 & 0.007 & 41 & 0.00 & 3 \\
\hline 11 & 0.17 & 12 & 92.11 & 34 & 0.003 & 10 & 0.05 & 48 & 53 & 0.12 & 51 & 72.11 & 62 & 0.008 & 48 & 0.06 & 51 \\
\hline 12 & 0.15 & 23 & 102.33 & 10 & 0.004 & 20 & 0.02 & 21 & 54 & 0.13 & 40 & 99.66 & 19 & 0.007 & 42 & 0.01 & 6 \\
\hline 13 & 0.16 & 21 & 101.83 & 11 & 0.004 & 21 & 0.04 & 39 & 55 & 0.10 & 58 & 71.88 & 64 & 0.014 & 70 & 0.24 & 84 \\
\hline 14 & 0.12 & 45 & 100.61 & 17 & 0.008 & 46 & 0.03 & 27 & 56 & 0.09 & 62 & 85.74 & 48 & 0.013 & 67 & 0.06 & 54 \\
\hline 15 & 0.18 & 7 & 99.16 & 20 & 0.002 & 6 & 0.01 & 12 & 57 & 0.07 & 74 & 80.59 & 54 & 0.017 & 75 & 0.05 & 45 \\
\hline 16 & 0.16 & 22 & 98.42 & 23 & 0.004 & 22 & 0.03 & 29 & 58 & 0.17 & 11 & 101.19 & 14 & 0.003 & 12 & 0.06 & 52 \\
\hline 17 & 0.12 & 44 & 96.42 & 27 & 0.007 & 38 & 0.00 & 2 & 59 & 0.20 & 2 & 113.33 & 1 & 0.001 & 2 & 0.04 & 36 \\
\hline 18 & 0.12 & 48 & 66.80 & 70 & 0.007 & 39 & 0.05 & 50 & 60 & 0.14 & 37 & 96.38 & 28 & 0.006 & 34 & 0.03 & 25 \\
\hline 19 & 0.06 & 75 & 63.94 & 73 & 0.018 & 76 & 0.09 & 63 & 61 & 0.10 & 61 & 93.66 & 32 & 0.012 & 63 & 0.01 & 16 \\
\hline 20 & 0.11 & 52 & 87.63 & 43 & 0.010 & 52 & 0.07 & 55 & 62 & 0.18 & 6 & 101.05 & 15 & 0.002 & 7 & 0.04 & 40 \\
\hline 21 & 0.10 & 60 & 77.39 & 55 & 0.012 & 60 & 0.04 & 42 & 63 & 0.14 & 31 & 69.07 & 67 & 0.007 & 43 & 0.16 & 73 \\
\hline 22 & 0.09 & 63 & 49.49 & 78 & 0.011 & 57 & 0.01 & 10 & 64 & 0.19 & 4 & 81.35 & 53 & 0.001 & 3 & 0.12 & 69 \\
\hline 23 & 0.05 & 80 & 31.87 & 83 & 0.022 & 80 & 0.19 & 78 & 65 & 0.17 & 14 & 94.79 & 30 & 0.003 & 13 & 0.05 & 47 \\
\hline 24 & 0.14 & 32 & 61.73 & 76 & 0.005 & 25 & 0.14 & 71 & 66 & 0.19 & 5 & 73.73 & 60 & 0.003 & 14 & 0.18 & 75 \\
\hline 25 & 0.05 & 81 & 63.73 & 74 & 0.023 & 81 & 0.20 & 80 & 67 & 0.14 & 26 & 100.30 & 18 & 0.005 & 26 & 0.04 & 38 \\
\hline 26 & 0.14 & 28 & 98.23 & 25 & 0.006 & 30 & 0.00 & 1 & 68 & 0.17 & 15 & 88.59 & 40 & 0.003 & 15 & 0.04 & 43 \\
\hline 27 & 0.09 & 64 & 85.96 & 47 & 0.013 & 66 & 0.04 & 37 & 69 & 0.14 & 27 & 103.20 & 6 & 0.005 & 27 & 0.01 & 17 \\
\hline 28 & 0.07 & 73 & 69.28 & 66 & 0.017 & 73 & 0.08 & 60 & 70 & 0.12 & 47 & 74.52 & 58 & 0.010 & 56 & 0.22 & 82 \\
\hline 29 & 0.14 & 36 & 108.00 & 2 & 0.006 & 31 & 0.01 & 8 & 71 & 0.16 & 17 & 86.78 & 45 & 0.003 & 16 & 0.03 & 33 \\
\hline 30 & 0.16 & 20 & 102.90 & 7 & 0.004 & 23 & 0.08 & 58 & 72 & 0.20 & 3 & 102.75 & 9 & 0.001 & 4 & 0.15 & 72 \\
\hline 31 & 0.11 & 53 & 93.48 & 33 & 0.010 & 53 & 0.04 & 35 & 73 & 0.12 & 46 & 86.44 & 46 & 0.008 & 49 & 0.01 & 7 \\
\hline 32 & 0.12 & 49 & 69.44 & 65 & 0.009 & 50 & 0.08 & 59 & 74 & 0.16 & 18 & 102.86 & 8 & 0.003 & 17 & 0.03 & 24 \\
\hline 33 & 0.13 & 41 & 89.22 & 39 & 0.008 & 47 & 0.05 & 44 & 75 & 0.17 & 16 & 101.41 & 13 & 0.003 & 18 & 0.01 & 13 \\
\hline 34 & 0.17 & 13 & 100.96 & 16 & 0.003 & 11 & 0.10 & 64 & 76 & 0.14 & 35 & 67.77 & 69 & 0.006 & 35 & 0.03 & 32 \\
\hline 35 & 0.11 & 56 & 65.97 & 71 & 0.010 & 54 & 0.11 & 66 & 77 & 0.18 & 8 & 105.64 & 3 & 0.002 & 8 & 0.10 & 65 \\
\hline 36 & 0.08 & 68 & 68.47 & 68 & 0.014 & 69 & 0.12 & 68 & 78 & 0.11 & 54 & 84.50 & 50 & 0.011 & 58 & 0.06 & 53 \\
\hline 37 & 0.06 & 77 & 62.43 & 75 & 0.017 & 74 & 0.03 & 28 & 79 & 0.14 & 29 & 95.16 & 29 & 0.006 & 36 & 0.03 & 26 \\
\hline 38 & 0.03 & 84 & 44.14 & 81 & 0.024 & 82 & 0.09 & 62 & 80 & 0.08 & 69 & 76.66 & 56 & 0.015 & 72 & 0.07 & 56 \\
\hline 39 & 0.10 & 59 & 82.89 & 51 & 0.010 & 55 & 0.02 & 19 & 81 & 0.10 & 57 & 89.68 & 38 & 0.011 & 59 & 0.18 & 77 \\
\hline 40 & 0.14 & 34 & 105.44 & 4 & 0.006 & 32 & 0.00 & 5 & 82 & 0.15 & 25 & 98.53 & 22 & 0.005 & 28 & 0.03 & 34 \\
\hline 41 & 0.09 & 65 & 85.32 & 49 & 0.012 & 61 & 0.03 & 30 & 83 & 0.18 & 9 & 104.54 & 5 & 0.002 & 9 & 0.07 & 57 \\
\hline 42 & 0.12 & 50 & 64.85 & 72 & 0.007 & 40 & 0.03 & 31 & 84 & 0.14 & 33 & 97.10 & 26 & 0.007 & 44 & 0.02 & 22 \\
\hline
\end{tabular}


According to the factor analysis, for the three variables studied, only one eigenvalue presented

Table 7. Spearman correlation coefficients of the adaptive and stability ranks of Eucalyptus clones, determined with the methods of Annicchiarico (ANN), Lin \& Binns, and Wricke (upper matrix), and Pearson correlation coefficient between the analyzed variables (lower matrix).

\begin{tabular}{|c|c|c|c|c|c|}
\hline \multirow[t]{2}{*}{ Variable } & \multicolumn{3}{|c|}{ Method } & \multicolumn{2}{|c|}{ Variable } \\
\hline & ANN & $\begin{array}{l}\text { Lin \& } \\
\text { Binns }\end{array}$ & Wricke & $\begin{array}{l}\text { Plant } \\
\text { height }\end{array}$ & $\begin{array}{l}\text { Volume } \\
\text { of wood }\end{array}$ \\
\hline & \multicolumn{5}{|c|}{ Average rank } \\
\hline Plant height & $0.991 * *$ & $0.979 * *$ & $0.510 * *$ & - & - \\
\hline DBH & $0.905^{* *}$ & $0.994 * *$ & $0.443 * *$ & - & - \\
\hline \multirow[t]{2}{*}{ Volume of wood } & $0.673 * *$ & $0.985^{* *}$ & $0.096^{\mathrm{ns}}$ & - & - \\
\hline & \multicolumn{5}{|c|}{ Annicchiarico rank } \\
\hline Plant height & - & $0.970 * *$ & $0.543 * *$ & - & - \\
\hline DBH & - & $0.926 * *$ & $0.744 * *$ & - & - \\
\hline \multirow[t]{2}{*}{ Volume of wood } & - & $0.657 * *$ & $0.419 * *$ & - & - \\
\hline & \multicolumn{5}{|c|}{ Lin \& Bins rank } \\
\hline Plant height & - & - & $0.609 * *$ & - & - \\
\hline DBH & - & - & $0.488 * *$ & - & - \\
\hline \multirow[t]{2}{*}{ Volume of wood } & - & - & $0.155^{\text {ns }}$ & - & - \\
\hline & \multicolumn{5}{|c|}{ Person correlation analysis } \\
\hline Plant height & & - & - & $0.845^{* *}$ & $0.966^{* *}$ \\
\hline DBH & & - & - & 1 & 0.846 \\
\hline Volume of wood & & - & - & & 1 \\
\hline
\end{tabular}

magnitude above 1 (Table 9). As the first factor explained relatively a small part of the variance, the second factor was considered to represent the variability of the data. Thus, the percentage of variance accumulated in the first two factors was above $80 \%$ for the three studied variables. By analyzing the factors after rotation, it was possible to group sites 1 and 3 in the first factor, leaving site 2, isolated in the second factor. With the identification of similar environments, the breeder has the potential to establish different breeding strategies for each group of environments, which can allow obtaining greater success in the selection process (Elias et al., 2016).

The clones present in quadrant I had wide adaptability, since they presented good performance in subregions 1 and 2 (Figure 1). The clones present in quadrant II showed specific adaptability for the subregion 2 - or for environment 2 -, while the clones in the quadrant IV showed specific adaptability for subregion 1, with environments 1 and 3 . Clones present in quadrant III presented low performance and could not be indicated.

Some disagreements around wide adaptation still remain in plant breeding programs. Baranski (2015) reported that genotypes should have as wide an adaptation as possible, meaning high and stable yields across different environments, and that this wide adaptation could be achieved by selecting only plants that do well in high fertility and irrigated environments. In agreement with this, Gallais \& Hirel (2004) reported that the selection in an ideal environment is more

Table 8. Average ranking $\left(\mu_{\mathrm{r}}\right)$ of the ten first Eucalyptus clones $(\mathrm{C})$ considering the ranking of the averages $(\mu)$, and the adaptability and stability ranks of the methods of Annicchiarico $\left(\mathrm{I}_{\mathrm{i}}\right)$, Lin \& Binns $\left(\mathrm{P}_{\mathrm{i}}\right)$, and Wricke $\left(\omega_{\mathrm{i}}\right)$, for the evaluated variables.

\begin{tabular}{|c|c|c|c|c|c|c|c|c|c|c|c|c|c|c|c|c|c|c|}
\hline \multirow[t]{2}{*}{ Rank } & \multicolumn{6}{|c|}{ Diameter at breast height } & \multicolumn{6}{|c|}{ Plant height } & \multicolumn{6}{|c|}{ Volume of wood } \\
\hline & $\mathrm{C}$ & $\mu$ & $\mathrm{I}_{\mathrm{i}}$ & $\mathrm{P}_{\mathrm{i}}$ & $\omega_{\mathrm{i}}$ & $\mu_{\mathrm{r}}$ & $\mathrm{C}$ & $\mu$ & $\mathrm{I}_{\mathrm{i}}$ & $\mathrm{P}_{\mathrm{i}}$ & $\omega_{\mathrm{i}}$ & $\mu_{\mathrm{r}}$ & $\mathrm{C}$ & $\mu$ & $\mathrm{I}_{\mathrm{i}}$ & $\mathrm{P}_{\mathrm{i}}$ & $\omega_{\mathrm{i}}$ & $\mu_{\mathrm{r}}$ \\
\hline 1 & 59 & 2 & 1 & 2 & 10 & 3.75 & 59 & 1 & 1 & 1 & 12 & 5 & 59 & 2 & 1 & 2 & 36 & 9.4 \\
\hline 2 & 15 & 4 & 2 & 3 & 13 & 5.5 & 62 & 7 & 5 & 11 & 35 & 12.6 & 15 & 7 & 20 & 6 & 12 & 15.8 \\
\hline 3 & 71 & 15 & 3 & 14 & 6 & 9.5 & 83 & 9 & 9 & 5 & 25 & 14.6 & 62 & 6 & 15 & 7 & 40 & 16.6 \\
\hline 4 & 62 & 6 & 6 & 6 & 28 & 11.5 & 72 & 8 & 8 & 6 & 31 & 15 & 74 & 18 & 8 & 17 & 24 & 17.4 \\
\hline 5 & 74 & 20 & 5 & 20 & 2 & 11.75 & 13 & 5 & 7 & 7 & 33 & 17 & 83 & 9 & 5 & 9 & 57 & 17.4 \\
\hline 6 & 75 & 13 & 7 & 10 & 20 & 12.5 & 12 & 15 & 15 & 13 & 16 & 17.2 & 12 & 23 & 10 & 20 & 21 & 20.4 \\
\hline 7 & 58 & 9 & 8 & 9 & 26 & 13 & 14 & 6 & 6 & 8 & 39 & 18.2 & 11 & 12 & 34 & 10 & 48 & 22.4 \\
\hline 8 & 10 & 8 & 9 & 7 & 29 & 13.25 & 69 & 19 & 18 & 15 & 8 & 18.2 & 75 & 16 & 13 & 18 & 13 & 22.6 \\
\hline 9 & 11 & 7 & 11 & 8 & 37 & 15.75 & 40 & 13 & 13 & 12 & 4 & 19.6 & 58 & 11 & 14 & 12 & 52 & 23.8 \\
\hline 10 & 68 & 11 & 14 & 12 & 35 & 18 & 67 & 14 & 14 & 14 & 23 & 20 & 1 & 19 & 21 & 19 & 49 & 24.2 \\
\hline
\end{tabular}


efficient, due the reduction of the genetic variability usually observed in nonideal environments. However, it seems logical that, although it might be possible to eventually define the characteristics of ideal plants, adapted to a specific environment, it would be much more difficult to define all possible combinations of a range of characteristics necessary to provide good adaptability in several environments (Rawlings, 2005).

Among the 84 evaluated clones, three $(9,59$, and 72) stood out for having the highest average values of $\mathrm{DBH}$, $\mathrm{PH}$, and VOW (Table 3). These results indicate the presence of variability in the clone bank tested, as well as the existence of superior clones, which can be maintained in the breeding program if they present productive stability and wide adaptability, responding to the improvement in the environment (Rosado et al., 2012).

Each evaluated method classified the clones into distinct ranks, which makes their recommendation a difficult task. According to the average ranking (Table 8), however, it can be inferred that clones 59 and 62 stood out as the most stable and adapted. The factor analysis reinforced this statement. Both clones were located in quadrant I, which characterizes them as broadly adaptable. Furthermore, they had the highest averages for the analyzed variables $(\mathrm{DBH}, \mathrm{PH}$, and

Table 9. Subgroups of environments for the variables diameter at breast height, plant height and volume of wood, according to the factor analysis method, considering 84 Eucalyptus clones and three growing environments.

\begin{tabular}{|c|c|c|c|c|}
\hline \multicolumn{2}{|c|}{ Eigen values } & \multicolumn{3}{|c|}{ Factor scores after rotation } \\
\hline$(\%)$ & Accumulated & Environment & Factor 1 & Factor 2 \\
\hline \multicolumn{5}{|c|}{ Diameter at breast height } \\
\hline 63.149 & 63.149 & 1 & 0.9052 & -0.2904 \\
\hline 30.078 & 93.228 & 2 & 0.4487 & 0.8924 \\
\hline 6.772 & 100.0 & 3 & 0.9348 & -0.1472 \\
\hline \multicolumn{5}{|c|}{ Plant height } \\
\hline 56.092 & 56.092 & 1 & 0.9062 & 0.1161 \\
\hline 32.848 & 88.940 & 2 & -0.1890 & 0.9819 \\
\hline 11.059 & 100.0 & 3 & 0.9088 & 0.0884 \\
\hline \multicolumn{5}{|c|}{ Volume of wood } \\
\hline 61.527 & 61.527 & 1 & 0.9377 & 0.0246 \\
\hline 29.802 & 91.330 & 2 & 0.1164 & 0.9908 \\
\hline 8.669 & 100.0 & 3 & 0.9057 & 0.2111 \\
\hline
\end{tabular}
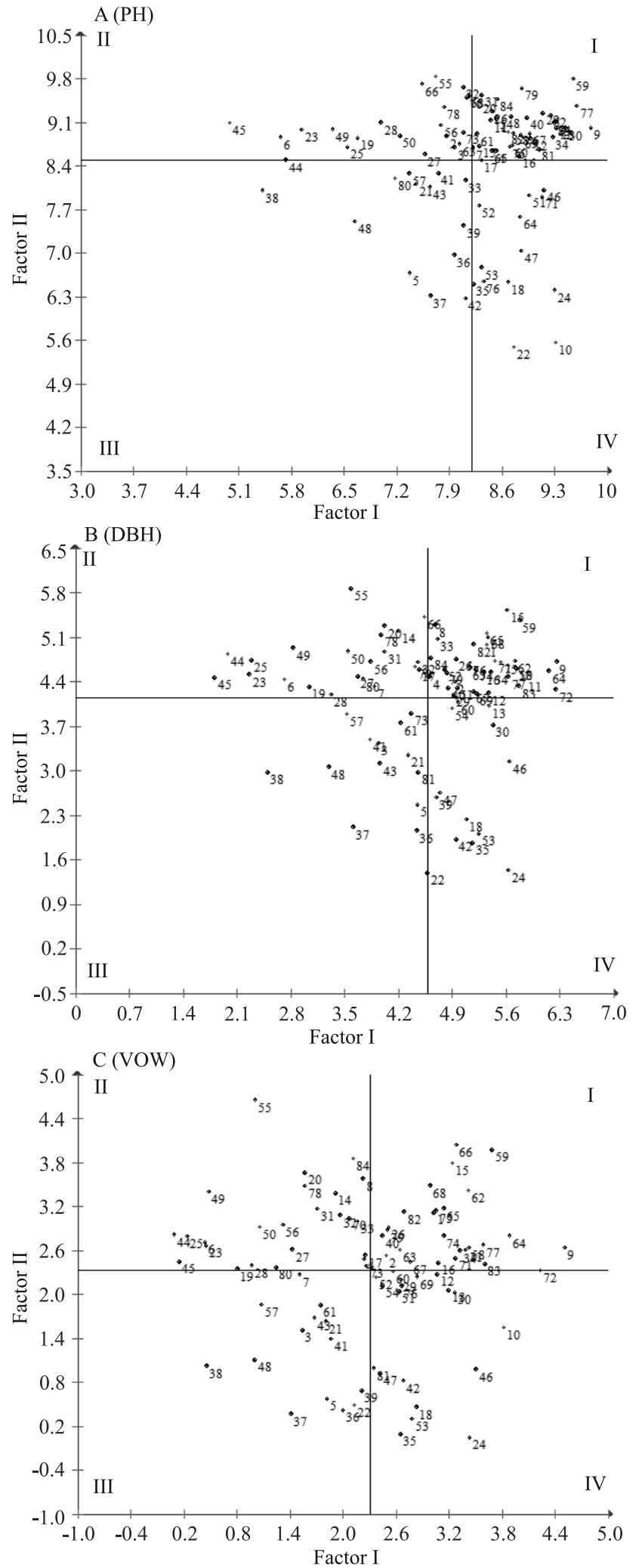

Figure 1. Distribution of factor analysis scores for the variables diameter at breast height (A), plant height (B), and volume of wood (C), considering 84 Eucalyptus clones evaluated in three environments. 
VOW). Therefore, these clones can contribute to the breeding program, showing wide adaptability, stability, and productive potential.

\section{Conclusions}

1. The methods of Annicchiarico and Lin \& Binns are highly associated with each other, and their use together with the method of Wricke is a sound strategy for the stability evaluation of Eucalyptus clones.

2. The use of the mean classification of the clones, along with factorial analysis, is efficient to identify the most adapted, stable, and productive ones among a high number of genotypes.

\section{References}

ANNICCHIARICO, P. Cultivar adaptation and recommendation from alfalfa trials in Northern Italy. Journal of Genetics and Breeding, v.4, p.269-278, 1992.

BARANSKI, M.R. Wide adaptation of green revolution wheat: international roots and the indian context of a new plant breeding ideal, 1960-1970. Studies in History and Philosophy of Science Part C: Studies in History and Philosophy of Biological and Biomedical Sciences, v.50, p.41-50, 2015. DOI: 10.1016/j. shpsc.2015.01.004.

CARVALHO, A.D.F. de; SILVA, G.O. da; PEREIRA, R.B. PINHEIRO, J.B. Análise de fatores e regressão bissegmentada no estudo da adaptabilidade e estabilidade de cenoura. Revista Ceres, v.61, p.932-940, 2014. DOI: 10.1590/0034-737X201461060007.

CRUZ, C.D. GENES: a software package for analysis in experimental statistics and quantitative genetics. Acta Scientiarum. Agronomy, v.35, p.271-276, 2013. DOI: 10.4025/ actasciagron.v35i3.21251.

CRUZ, C.D.; REGAZZI, A.J.; CARNEIRO, P.C.S. Modelos biométricos aplicados ao melhoramento genético. 4.ed. Viçosa: Ed. da UFV, 2012.

ELIAS, A.A.; ROBBINS, K.R.; DOERGE, R.W.; TUINSTRA, M.R. Half a century of studying genotype $\times$ environment interactions in plant breeding experiments. Crop Science, v.56, p.2090-2105, 2016. DOI: 10.2135/cropsci2015.01.0061.

GALLAIS, A.; HIREL, B. An approach to the genetics of nitrogen use efficiency in maize. Journal of Experimental Botany, v.55, p.295-306, 2004. DOI: 10.1093/jxb/erh006.

LEITE, H.G.; CAMPOS, J.C.C.; PAULA JUNIOR, G.G.P. Emprego de um modelo de programação dinâmica para conversão de troncos em multiprodutos da madeira. Revista Árvore, v.19, p.447-465, 1995.
LIN, C.S.; BINNS, M.R. A superiority measure of cultivar performance for cultivar $\times$ location data. Canadian Journal of Plant Science, v.68, p.193-198, 1988. DOI: 10.4141/cjps88-018.

LIN, C.S.; BINNS, M.R. Genetic properties of four types of stability parameter. Theoretical and Applied Genetics, v.82, p.505-509, 1991. DOI: 10.1007/BF00588606.

MURAKAMI, D.M.; CRUZ, C.D. Proposal of methodologies for environment stratification and analysis of genotype adaptability. Crop Breeding and Applied Biotechnology, v.4, p.7-11, 2004.

NUNES, G.H. de S.; REZENDE, G.D.S.P.; RAMALHO, M.A.P.; SANTOS, J.B. dos. Implicações da interação genótipo $\mathrm{x}$ ambientes na seleção de clones de eucalipto. Cerne, v.8, p.49-58, 2002.

PAULA, R.R.; REIS, G.G.; REIS, M.G.F.; OLIVEIRA NETO, S.N.; LEITE, H.G.; MELIDO, R.C.N.; LOPES, H.N.S.; SOUSA, F.C. Eucalypt growth in monoculture and silvopastoral systems with varied tree initial densities and spatial arrangements. Agroforestry Systems, v.87, p.1295-1307, 2013.

PEREIRA, H.S.; MELO, L.C.; DEL PELOSO, M.J.; FARIA, L.C. de; COSTA, J.G.C. da; DÍAZ, J.L.C.; RAVA, C.A.; WENDLAND, A. Comparação de métodos de análise de adaptabilidade e estabilidade fenotípica em feijoeiro-comum. Pesquisa Agropecuária Brasileira, v.44, p.374-383, 2009. DOI: 10.1590/S0100-204X2009000400007.

RAWLINGS, D.E. Characteristics and adaptability of iron- and sulfur-oxidizing microorganisms used for the recovery of metals from minerals and their concentrates. Microbial Cell Factories, v.4, p.1-15, 2005. DOI: 10.1186/1475-2859-4-13.

RESENDE, M.D.V.; SILVA, F.F.; LOPES, P.S.; AZEVEDO, C.F. Seleção Genômica Ampla (GWS) via Modelos Mistos (REML/BLUP), Inferência Bayesiana (MCMC), Regressão Aleatória Multivariada (RRM) e Estatística Espacial. Viçosa: Universidade Federal de Viçosa, Departamento de Estatística, 2012. 291p.

ROCHA, M. das G. de B.; PIRES, I.E.; ROCHA, R.B.; XAVIER, A.; CRUZ, C.D. Avaliação genética de progênies de meio-irmãos de Eucalyptus grandis por meio dos procedimentos REML/BLUP e da ANOVA. Scientia Forestalis, v.71, p.99-107, 2006.

ROSADO, A.M.; ROSADO, T.B.; ALVES, A.A.; LAVIOLA, B.G.; BHERING, L.L. Seleção simultânea de clones de eucalipto de acordo com produtividade, estabilidade e adaptabilidade. Pesquisa Agropecuária Brasileira, v.47, p.964971, 2012. DOI: 10.1590/S0100-204X2012000700013.

SILVA, W.C.J. e; DUARTE, J.B. Métodos estatísticos para estudo de adaptabilidade e estabilidade fenotípica em soja. Pesquisa Agropecuária Brasileira, v.41, p.23-30, 2006. DOI: 10.1590/ S0100-204X2006000100004.

WRICKE, G. Zur Berechnung der Ökovalenz bei Sommerweizen und Hafer. Pflanzenzüchtung, v.52, p.127-138, 1965.

Received on January 4, 2016 and accepted on June 12, 2017 